\title{
Cultural Significance of Medicinal Plants in Healing Human Ailmets Among Guji Semi-Pastoralist People, Suro Barguda District, Ethiopia
}

Mersha Eshete Ashagre ( $\triangle$ mae19590917@gmail.com )

Addis Ababa University https://orcid.org/0000-0001-6133-8521

Ermias Lulekal Molla

Addis Ababa University Faculty of Science: Addis Ababa University College of Natural Sciences

\section{Research Article}

Keywords: Human ailments, Indigenous knowledge, Medicinal plants, Suro Barguda District.

Posted Date: March 30th, 2021

DOl: https://doi.org/10.21203/rs.3.rs-345526/v1

License: (c) (1) This work is licensed under a Creative Commons Attribution 4.0 International License.

Read Full License 


\section{Abstract}

Background: Ethnobotanical studies are useful in documenting, analyzing, and communicating knowledge and interaction between plant diversity and human societies. Indigenous knowledge has developed as a result of human interaction with their environment. Overstocking and farmland expansion has become the main causes of natural resource degradation. Studies on the ethnobotany of the woodland and dry Afromontane vegetation in Suro Barguda District are lacking. So, it was important to study the diversity of medicinal plants and associated indigenous knowledge to determine the level of their usage, depletion, or conservation.

Methods: Ethnobotanical data of traditional medicinal plants were collected by interviewing 196 informants (145 males and 51 females). Guided field walks and discussions (both group and individual discussion) were used in collecting the data. Quantitative approaches were used to determine the informant consensus factor, fidelity level, and use-value. Ethnomedicinal knowledge apprehended by different informant categories was compared using t-tests with R- software.

Results: A total of 98 medicinal plant species belonging to 87 genera and 48 families were reported to be used for treating human ailments. Family Fabaceae was represented by the highest number of species followed by Lamiaceae. Four of the medicinal plants were endemic to Ethiopia. Shrubs were more dominant than trees and herbs. Most of the remedy preparations were from freshly collected plant parts; the major way of herbal medicine preparation was through chopping or pounding the plant parts and homogenizing them with cold and clean water; the oral application was the most common route of administration.

Conclusion: The study area was rich in having medicinal plants and corresponding indigenous knowledge diversity. Most of the medicinal plants were found to play a multipurpose role across different use categories and consequently, some are under serious pressure challenging their survival. Hence, recorded high use value indices of multipurpose plant species in the study area can be used as signals of high use pressure and can be used as keys to design and implement well-coordinated complementary in situ and ex situ conservation activity to save these widely used plant species.

\section{Background}

Ethnobotany is defined as "local people's interaction with the natural environment: how they classify, manage and use plants available around them" [1]. Indigenous knowledge has developed as a result of human interaction with their environment. So, ethnobotanical studies are useful in documenting, analyzing, and communicating knowledge and interaction between plant diversity and human societies, how diversity in nature is used and influenced by human activities $[1,2,3]$. In discussing the many potential uses and ways of interacting with local plants, we anticipated expressing a sense of the value of the study area landscapes with the associated vegetation and respective indigenous knowledge. Traditional knowledge is coming into the middle-of-the-road for sustainable development and biodiversity 
conservation discussion. Indigenous knowledge guides the choices and practices of pastoralists and farmers of many places and, predictably, some $80 \%$ of the world's population fulfills their primary health needs through the use of traditional medicines [4]. Even in developed countries, local knowledge built up across generations continues to play a fundamental role in supporting localized resource use practices whether they are pastoralists, small-scale farmers, or the gatherers of wild produce. Indigenous people can contribute importantly to the understanding of the processes of change, whether these might be short, or long-term which can be bounded to local events or global transformation processes. Pastoral and peasant communities that have maintained traditional modes of production have today become the major guardians of the world's crop and domestic animal diversity. However, overstocking and farmland expansion has become the main causes of natural resource degradation. Despite these, studies on the ethnobotany of the woodland and dry Afromontane vegetation in Suro Barguda District are lacking. So, it was important to study the diversity of medicinal plants and associated indigenous knowledge in the study area to determine the level of their usage, depletion/ conservation.

\section{Traditional medicinal plants}

In Ethiopia, there is limited development of therapeutic products and the indigenous knowledge on the practice of medicinal plants as traditional remedies are being lost owing to migration from rural to urban areas, industrialization, fast loss of natural habitats, and transformations in lifestyle. There is also a lack of adequate ethnobotanical surveys carried out in many parts of the country. Because of these, records of the traditional use of medicinal plants is an urgent matter and important to preserve the knowledge $[5,6]$. The socio-cultural appeal, the cultural acceptability of healers and local pharmacopeias, accessibility, being fair in its price, and effectiveness against several health problems seem to foster its widespread use $[7,8]$. The Ethiopian traditional medical system is characterized by variation and is shaped by the environmental diversities of the country, socio-cultural conditions of the different ethnic groups as well as historical developments that are related to migration, the introduction of foreign culture, and religion [9, $10,11,12]$. Traditional medical practitioners treat people and most of the health services rendered by these practitioners are focused on communicable diseases among people. Proper management of traditional medicinal plant resources is essential, not only because of their value as a potential source of new drugs but due to reliance on traditional medicinal plants for health. Ethnobotanical studies can indicate management problems of medicinal plants through interviews and market surveys and it gives solutions by promoting local traditions and customs that had conservation merits [13, 14]. Therefore, people living in Suro Barguda District have traditional practices which they put into effect for generations to take care of themselves. On the other hand, the area has been losing its indigenous flora over what went before due to human and other biotic and natural causes. This loss of forests associates with the missing of important indigenous knowledge connected with the plants. Hence, there is a clear need to conduct an ethnobotanical study on the diverse medicinal plants in the area, to look into and compile relevant information, and to document them before it becomes difficult to gain the knowledge of the indigenous people. 


\section{Materials And Methods}

\section{Description of the study area}

The present study was conducted in Suro Barguda District, West Guji Zone of Oromia Regional State, southern Ethiopia. Suro Barguda District is located $497 \mathrm{~km}$ south of Addis Ababa - the capital of Ethiopia, and $30 \mathrm{~km}$ from Bule Hora town, the capital of West Guji Zone. The district is generally characterized by rough and rugged topography and lies between latitudes $5^{\circ} 30^{\prime} 0^{\prime \prime} \mathrm{N}$ and $5^{\circ} 50^{\prime} 0^{\prime \prime} \mathrm{N}$, and longitudes $37^{\circ} 50^{\prime} 0^{\prime \prime} \mathrm{E}$ and $38^{\circ} 20^{\prime} 0^{\prime \prime} \mathrm{E}$. The altitude ranges from 900 to 2350 m.a.s.l. Suro Barguda District's Land Administration Office reported (unpublished annual report) that the total area of the district is $154,958.4$ hectares (Figure 1).

Suro Barguda District is divided into two agro-ecological zones, namely the lowlands (from $900-1500 \mathrm{~m}$ a.s.l) and the middle altitude ranging from 1501-2500 $\mathrm{m}$ a.s.l. Accordingly, the proportion of the two agroclimatic zones in the district is $41.8 \%$ lowlands and $58.2 \%$ mid-altitude. Suro Barguda District falls within the southern bimodal rainfall regime of Ethiopia (Fig. 2). Since there was no Meteorological Station at Suro Barguda District, fifteen years of Meteorological data (2004 - 2018) registered by the nearby Station (Bule Hora District Station) was taken from National Meteorological Service Agency. Based on the analysis of this data the district receives high rainfall between March and half of June as well as a relatively good amount from half of August to half of November. The dry season extends from December to February and some extent from half of June to half of August. The highest mean annual average rainfall of the study area within fifteen years was $171.3 \mathrm{~mm}$ recorded in May, whereas the lowest mean average was $12.4 \mathrm{~mm}$ recorded in February. The lowest mean average temperature over fifteen years was 10.8 Co recorded in December whereas the highest was 28.7 Co recorded in February. The mean annual rainfall of the study area was $853 \mathrm{~mm}$ whereas the mean annual temperature was $19.8 \mathrm{Co}$. Based on [15] classification of Ethiopian vegetation the study area vegetation is included in Acacia - Commiphora woodland and Bushland, Combretum-Terminalia Woodland, and Dry Evergreen Afro-montane Forest and Grassland complex.

Bule Hora (1984 m a.s. I.)

2004-2018 $19.8 c^{\circ} \quad 853 \mathrm{~mm}$

\section{Demographics and human health condition in the district}

Since Suro Barguda District was established recently, a population census is not carried out. But the district is predominantly $(99.9 \%)$ occupied by Guji Oromo people who speak the Oromo language with unique dialect and the majority of the residents live in rural areas. Pastoralism with subsistence farming is the most common economic mainstay of the people. In one or another way, their livelihoods depend upon the presence of different plant species and vegetation. As in most rural districts of Ethiopia, access to modern health services is poor. Based on the 2016 -2018 District's Health Office report (unpublished annual report, 2018), 41,030 people were assisted by modern health service which covers only $55 \%$ of the 
population. There are two governmental health centers and eight health posts in Suro Barguda District. Concerning human health professionals in the district, there were three health officers, two nurses, 40 clinical nurses, two laboratory technicians, one sanitarian, eight midwives, one pharmacist, 54 health extension workers, and 10 support staff. The five common health problems in the district were acute respiratory tract infection, pneumonia, typhoid, internal parasitoid, different types of cancer symptoms, and malaria.

\section{Study site selection}

A reconnaissance survey of the study area was conducted from May $06-21,2019$ to obtain information about the agro-ecology of the area, status of the vegetation, indigenous knowledge of the local people in using plants for different purposes and determine the sites from where and how the data should be collected. The study district had 10 semi-pastoralist kebeles (the smallest administrative units) and currently, these kebeles are rearranged/subdivided to be 19 kebeles to decentralize the administration processes. Study sites from the ten kebeles were selected based on distance from the administrative town (Suro town), and presence/absence of health facilities for collecting medicinal plant information.

\section{Informant size determination}

The informant size for collecting quantitative and qualitative data for medicinal plants research to ensure the required representative size of households from all semi-pastoralist kebeles was followed Cochran's (1977) formula as indicated by [16]. Informants were included from different age and sex groups of households of the 10 semi-pastoralist kebeles in the district.

$$
\mathbf{n}=\frac{N}{1+N(e)=}
$$

Where,

$\mathrm{n}=$ sample size for the research; $\mathrm{N}=$ total number of households in all the 10 kebeles.

$\mathrm{e}=$ maximum variability or margin of error $5 \%(.05)$;

$1=$ the probability of the event occurring.

The total number of households in the 10 pastoralists' kebeles of the district was 386 . Hence, the informant sample size comes to;

$$
\begin{array}{cc}
=\underline{386}=\underline{386}=196 \text { informants } \\
1+386(0.05)^{2} \quad 1.965
\end{array}
$$

Therefore, the required informants (respondents) size was 196. Informants' size for each kebele was calculated using the amount of the number of households in each kebele to the total number of 
households of the 10 kebeles i. e.

Informants from each kebele $=$ Number of households of the kebele $X$ Total number of informants/Total number of households.

For example, the informant size of Dembela Hara with a total household of 47 was 24 , i.e. $(47 \times 196 / 386$ =24). The same calculation was used for the other study kebeles and two to four key informants were taken purposefully from each kebele based on the size of the households (a total of 24 key informants) including healers, herbalists, elders, and practitioners based on their knowledge as recommended by the local people. The purposive sampling technique is most effective when one wants to study a certain cultural domain with experts within the native people. The remaining 172 general informants (respondents) were taken by random sampling method to make sure that important informant categories from different age and sex groups are included (Table 1).

Table 1. Number of households and informants included for the ethnobotanical data collection

\begin{tabular}{|c|c|c|c|c|c|c|c|c|c|c|c|}
\hline \multirow[t]{2}{*}{ No } & \multirow[t]{2}{*}{$\begin{array}{l}\text { Name of the } \\
\text { kebele }\end{array}$} & \multirow[t]{2}{*}{$\begin{array}{l}\text { Total number of } \\
\text { households }\end{array}$} & \multicolumn{3}{|c|}{$\begin{array}{l}\text { Key } \\
\text { informants }\end{array}$} & \multicolumn{3}{|c|}{$\begin{array}{l}\text { Randomly taken } \\
\text { informants }\end{array}$} & \multicolumn{3}{|c|}{ Total informants } \\
\hline & & & $M$ & $\mathrm{~F}$ & $\mathrm{~T}$ & $M$ & $\mathrm{~F}$ & $\mathrm{~T}$ & $M$ & $\mathrm{~F}$ & $\mathrm{~T}$ \\
\hline 1 & $\begin{array}{l}\text { Dembela } \\
\text { Hara }\end{array}$ & 47 & 2 & 1 & 3 & 17 & 4 & 21 & 19 & 5 & 24 \\
\hline 2 & Didole Hara & 43 & 2 & 1 & 3 & 15 & 4 & 19 & 17 & 5 & 22 \\
\hline 3 & $\begin{array}{l}\text { Gelana } \\
\text { Meteri }\end{array}$ & 36 & 2 & 0 & 2 & 14 & 2 & 16 & 16 & 2 & 18 \\
\hline 4 & Hidha Korma & 37 & 2 & 0 & 2 & 15 & 2 & 17 & 17 & 2 & 19 \\
\hline 5 & Mediba & 40 & 2 & 1 & 3 & 14 & 3 & 17 & 16 & 4 & 20 \\
\hline 6 & Meteri & 31 & 2 & 0 & 2 & 13 & 1 & 14 & 15 & 1 & 16 \\
\hline 7 & $\begin{array}{l}\text { Motokoma } \\
\text { Hara }\end{array}$ & 39 & 2 & 0 & 2 & 16 & 2 & 18 & 18 & 2 & 20 \\
\hline 8 & $\begin{array}{l}\text { Sororo Melka } \\
\text { Jewe }\end{array}$ & 34 & 2 & 0 & 2 & 13 & 2 & 15 & 15 & 2 & 17 \\
\hline 9 & $\begin{array}{l}\text { Soyama } \\
\text { Suro }\end{array}$ & 40 & 2 & 1 & 3 & 15 & 2 & 17 & 17 & 3 & 20 \\
\hline \multirow[t]{2}{*}{10} & $\begin{array}{l}\text { Welena } \\
\text { Bokosa }\end{array}$ & 39 & 2 & 0 & 2 & 16 & 2 & 18 & 18 & 2 & 20 \\
\hline & Total & 386 & 20 & 4 & 24 & 148 & 24 & 172 & 168 & 28 & 196 \\
\hline
\end{tabular}


Data collection was conducted two times; from July 01 to August 30, 2019, and November, 15 to December 30, 2019, and plants reported as medicine by the informants were collected. Ethnobotanical data were collected following $[1,3,17]$. Semi-structured interviews, guided field walks, discussions, market surveys, and field observation, with randomly picked and key informants, were applied based on a checklist of questions. The selected informants in the sample site were interviewed using semi-structured interview which was translated into the local language (Oromo language) focusing on medicinal plants: their uses and management; from where they collect them; how could they manage if these plants cause negative side effect on users; which plant was more preferable in its use; how they know their habitat and time of availability; whether they got any economic benefit from medicinal plants or not; whether they had any tendency to cultivate some selected medicinal plants or not; about the level of any threat to the medicinal plants; what they suggest about the current conservation status of these plants; how widespread the medicinal plant/s in the area; whether there was disappeared medicinal plant or not; as there was any restriction or taboo in collecting medicinal plants or not; whether these plants had other purposes or not; etc.

A semi-structured interview questionnaire was an important tool for the collection of both qualitative and quantitative data at the same time. The informants participated in answering the questions by showing the plants that they used as a medicine during the guided field walk interview. An explanatory individual and group discussion were made with the informants at each locality and site focusing on the status of the vegetation and acceptance of medicinal plants by the community. Detailed Notes on facts and information about the respondents, history of medicinal plant users, status of medicinal plants, and other essential information (based on the questionnaire) were taken on site. During the discussion, the informants were free to explain about medicinal plants and their knowledge without being interfered with and restricted.

\section{Ethnobotanical data analysis}

Ethnobotanical data were analyzed following the basic analytical tools $[1,18,19]$. Potentially effective medicinal plants were identified by the method of informant consensus factor [20]. So, rank-ordering (Preference ranking) of medicinal plants was used to determine their order of cultural importance across a community. The most important in the set was given the highest number, decreasing in number as the members of the set decrease in importance. Preference ranking was computed by taking 10 key informants to assess the degree of effectiveness those medicinal plants highly cited by the informants used to treat a particular disease [1]. Direct matrix ranking was a more multifaceted version of preference ranking. Here informants order medicinal plants by considering several attributes one at a time, i.e. it draws explicitly upon multiple dimensions. Direct matrix ranking was performed as a group exercise in which participants reach a consensus on the ranking of each item based on their evaluations [1]. The ranking of threats on 10 medicinal plants that were reported by most of the informants in the study area was conducted using ten key informants as described by [1] and [21]. This information was used to determine the highest threats to traditional medicinal plants in the study area and help to suggest appropriate conservation measures as considered. Informant consensus factor (ICF) was considered for 
each group of ailments to identify the agreement of the informants on the reported cures for the group of aliments of the plant. ICF was computed as follows: the number of use citations in each group $\left(\mathrm{n}_{\mathrm{ur}}\right)$ minus the number of species used $\left(n_{t}\right)$, divided by the number of use citations in each group minus one [22]. The mentioned ailments were grouped and then the ICF values were calculated as:

$$
I C F=\frac{n_{u r}-n_{t}}{n_{u r}-1}
$$

Medicinal plants that were effective in treating groups of ailments had a higher informant consensus factor value.

The Fidelity level (FL) computes the significance of a species for a given purpose. Most commonly used medicinal plants had high fidelity level value. The fidelity level $(\mathrm{FL})$ among medicinal plants of the study area was computed based on the following formula: $\mathrm{FL}=\mathrm{Np} / \mathrm{N}$. To calculate the percentage of Fidelity level: $F L \%=(\mathrm{Np} / \mathrm{N}) \times 100$ was used [2]. $\mathrm{Np}$ is the number of informants who independently cited the importance of a species to treat a particular disease, and $\mathrm{N}$ is the total number of informants who reported the plant to treat any given disease.

The local importance of each species cited in the study area was calculated using Use-Value (UV) technique following [23]. Use-Value (UV) is a quantitative method that demonstrates the relative importance of species known locally, which reflects the importance of each species to informants i. e.

UVis $=\Sigma$ Uis $/$ nis

Where UVis = use the value of a species s for informant $\mathbf{i}$,

$U_{\text {is }}=$ the number of uses mentioned in each event by informant $\mathbf{i}$, and

$\mathrm{n}_{\text {is }}=$ the number of events for species s with informant I

\section{Results}

\section{Medicinal plants diversity}

A total of 98 medicinal plant species belonging to 87 genera and 48 families were reported to be used for treating human ailments in Suro Barguda District (Appendix 1). Family Fabaceae was represented by the highest number of species (10 species, 10.2\%), followed by Lamiaceae (seven species, 7.1\%). Four of the medicinal plants which were used to treat human ailments were endemic to Ethiopia. Identified growth forms of medicinal plants indicated that shrubs $(36 ; 36.7 \%)$ were more dominant than trees $(30 ; 30.6 \%)$ and herbs $(14 ; 14.3 \%)$. Other forms such as lianas, climbing herbs, epiphytes and succulent were 11 species $(11.2 \%)$, three species (3.1\%), three species (3.1\%), and one species $(1.0 \%)$ respectively.

\section{Medicinal plant parts used}


Even though about eight different plant parts were reported to be used for remedy preparation in different ways, a larger proportion (36.2\%) of the preparations were obtained from leaves followed by roots (23.8\%) and barks (18.6\%). In addition to this, the stem was used for $5.7 \%$ preparations, whereas the latex alone and the leaves in mixture with other plant parts $5.2 \%$ respectively (Figure 3 ). Most of the remedy preparations $(93.7 \%)$ were reported as they were prepared from freshly collected plant parts, $5.8 \%$ from dried parts and the remaining $(0.5 \%)$ were prepared either from the fresh or dried plant parts.

\section{Ways of herbal medicine preparation}

As herbalists reported in the study area, ways of preparing remedies vary based on the type of ailment which they identified regarding symptoms observed on patients. The major way of herbal medicine preparation was through chopping or pounding the plant parts and homogenizing it with cold and clean water (35.6\%) followed by crushing and put on the preparation (16.7\%) and chopping, homogenizing, and boiling the preparation (15\%) (Figure 4).

\section{Route of remedy administration}

Results of analysis of route of administration of medicinal preparations revealed that oral application was the most common route of administration (159 preparations, $70.4 \%$ ) followed by dermal administration (49 preparations, $21.7 \%$ ) and nasal administration (12 preparations, 5.3\%). Other remedies were reported to be administered through a deep opening on the body formed due to infection "Luxaa - in local Oromo language or tissue cancer" (three preparations, $1.3 \%$ ); aural (two preparations; $0.9 \%$ ), or ocular (one preparation; $0.4 \%$ ) concerning the type of ailment reported by diagnosing the patient.

\section{Major types of diseases occurred in the study area with their clinical explanation}

Out of the fifty-nine mentioned human diseases, thirty-one were considered for their traditional versus clinical explanations as indicated in Table 2.

\section{The most preferred medicinal plants for treating human ailments}

Preference ranking exercise on medicinal plant species that were reported to be used against toothache, which was one of the gastrointestinal diseases common to the study area, showed the most effective medicinal plants (Table3).

Table 3. Results of preference ranking of ten medicinal plants reported for treating toothache 


\begin{tabular}{|c|c|c|c|c|c|c|c|c|c|c|c|c|}
\hline \multirow{2}{*}{$\begin{array}{l}\text { Medicinal plants used } \\
\text { for tooth ache }\end{array}$} & \multicolumn{10}{|c|}{ Informants designated $\mathrm{A}$ to $\mathrm{J}$} & \multirow[t]{2}{*}{ Total } & \multirow[t]{2}{*}{ Rank } \\
\hline & A & B & C & D & E & $\mathbf{F}$ & G & $\mathrm{H}$ & $\mathbf{I}$ & $J$ & & \\
\hline Acmella caulirhiza & 8 & 5 & 6 & 7 & 4 & 2 & 3 & 1 & 8 & 1 & 45 & $10^{\text {th }}$ \\
\hline Capparis tomentosa & 8 & 9 & 7 & 6 & 4 & 5 & 3 & 8 & 1 & 2 & 53 & $7^{\text {th }}$ \\
\hline Carissa spinarum & 8 & 9 & 7 & 10 & 6 & 4 & 5 & 3 & 1 & 7 & 60 & $3^{\text {rd }}$ \\
\hline $\begin{array}{l}\text { Clerodendrum } \\
\text { myricoides }\end{array}$ & 10 & 8 & 9 & 7 & 10 & 10 & 3 & 1 & 10 & 2 & 70 & $1^{\text {st }}$ \\
\hline Fagaropsis angolensis & 8 & 6 & 7 & 9 & 10 & 5 & 3 & 4 & 4 & 3 & 59 & $4^{\text {th }}$ \\
\hline Pappea capensis & 7 & 6 & 5 & 8 & 4 & 8 & 3 & 1 & 3 & 2 & 47 & $9^{\text {th }}$ \\
\hline $\begin{array}{l}\text { Pittosporum } \\
\text { viridiflorum }\end{array}$ & 8 & 7 & 9 & 6 & 4 & 5 & 9 & 1 & 4 & 3 & 56 & $5^{\text {th }}$ \\
\hline Premna schimperi & 7 & 8 & 6 & 4 & 5 & 3 & 1 & 8 & 3 & 4 & 49 & $8^{\text {th }}$ \\
\hline Rhoicissus revoilii & 9 & 7 & 6 & 8 & 5 & 4 & 2 & 9 & 3 & 1 & 54 & $6^{\text {th }}$ \\
\hline Scherebra alata & 9 & 10 & 8 & 7 & 5 & 6 & 10 & 4 & 2 & 3 & 64 & $2^{\text {nd }}$ \\
\hline
\end{tabular}

N.B. Scores in the table indicate ranks given to medicinal plants based on their efficacy. The highest number (10) given for the medicinal plant which informants thought was most effective in treating toothache and the lowest number (1) for the least effective plant selected currently for this ranking purpose from numerous medicinal plants used to treat this disease.

Consensuses on the most frequently used medicinal plants used for treating human ailments in the study area

This study clarified that some medicinal plants were well known in the study area than others. As a result, all key informants cited such plants repeatedly as a remedy for various diseases of humans. For example, Justicia schimperiana and Warburgia ugandensis were cited by all key informants $(100 \%)$ as sources of remedy for hepatitis and internal organ cancer respectively. Carissa spinarum, Ocimum urticifolium and Schrebera alata were also cited by 23 (95.8\%) key informants as sources of remedy for breast disease, febrile illness, and tooth cancer respectively (Table 4). 
Table 4. Key informants consensus on most commonly used medicinal plants

\begin{tabular}{|llll|}
\hline The botanical name of medicinal plants & Disease treated & No. of key informants & $\%$ \\
\hline Carissa spinarum & Breast disease & 23 & 95.8 \\
\hline Clerodendrum myricoides & Gonorrhea & 22 & 91.7 \\
\hline Haplocoelum foliolosum & Parasitic worms & 21 & 87.5 \\
\hline Fagaropsis angolensis & Coughing & 20 & 83.3 \\
\hline Ocimum urticifolium & Febrile illness & 23 & 95.8 \\
\hline Justicia schimperiana & Hepatitis & 24 & 100 \\
\hline Rhus vulgaris & Itching & 19 & 79.2 \\
\hline Schrebera alata & Tooth cancer & 23 & 95.8 \\
\hline Warburgia ugandensis & Internal organ cancer & 24 & 100 \\
\hline Withania somnifera & Snake venom & 20 & 83.3 \\
\hline
\end{tabular}

\section{Effectiveness of medicinal plants}

Informant consensus was used to evaluate the reliability of the data. To simplify the analysis, twelve disease categories were designated from the total 59 human ailments reported in the district and ICF values were computed based on the reported medicinal plant species and their use citations for each disease category, and the following results were obtained (Table 5).

Table 5. ICF values of traditional medicinal plants used for treating human ailments 


\begin{tabular}{|c|c|c|c|c|c|c|}
\hline No & Disease category & $\begin{array}{l}\text { No. of } \\
\text { spp. }\end{array}$ & $\begin{array}{l}\% \text { all } \\
\text { spp. }\end{array}$ & $\begin{array}{l}\text { Use } \\
\text { citation }\end{array}$ & $\begin{array}{l}\% \text { all use } \\
\text { citation }\end{array}$ & ICF \\
\hline 1 & $\begin{array}{l}\text { Dental, oral and pharyngeal } \\
\text { diseases }\end{array}$ & 15 & 35.5 & 76 & 38.8 & 0.81 \\
\hline 2 & Dermatological diseases & 14 & 21.1 & 136 & 69.4 & 0.90 \\
\hline 3 & $\begin{array}{l}\text { Diabetics, hepatitis, and } \\
\text { hypertension }\end{array}$ & 12 & 15.8 & 39 & 19.9 & 0.71 \\
\hline 4 & Evil spirit diseases & 7 & 9.2 & 24 & 12.2 & 0.73 \\
\hline 5 & External injuries and snake bite & 13 & 30.3 & 72 & 36.7 & 0.83 \\
\hline 6 & Febrile diseases & 5 & 6.6 & 58 & 29.6 & 0.90 \\
\hline 7 & Gastrointestinal diseases & 16 & 6.6 & 194 & 99.0 & 0.92 \\
\hline 8 & $\begin{array}{l}\text { Musculoskeletal and nervous } \\
\text { system }\end{array}$ & 13 & 56.6 & 68 & 34.7 & 0.82 \\
\hline 9 & Breathing system diseases & 15 & 7.9 & 160 & 81.6 & 0.91 \\
\hline 10 & Sensorial diseases & 13 & 17.1 & 42 & 21.4 & 0.70 \\
\hline 11 & Tissue cancer and cold disease & 12 & 38.2 & 40 & 20.4 & 0.72 \\
\hline 12 & $\begin{array}{l}\text { Urogenital and venereal } \\
\text { diseases }\end{array}$ & 9 & 25.0 & 33 & 16.8 & 0.75 \\
\hline
\end{tabular}

The relative healing potential of medicinal plants used for treating human ailments

Fidelity level values of medicinal plants commonly reported against a given human ailment category were computed to know the healing potential of the reported medicinal plants against the corresponding diseases and the following results were obtained (Table 6).

Table 6. Fidelity level values of medicinal plants commonly reported against a given human ailment category 


\begin{tabular}{|llllll|}
\hline No & Medicinal plant & Therapeutic category & Np & N & FL (\%) \\
\hline 1 & Combretum molle & Gastro - intestinal parasites & 28 & 29 & 97 \\
\hline 2 & Fagaropsis angolensis & Breathing system diseases & 23 & 24 & 96 \\
\hline 3 & Ocimum urticifolium & Febrile diseases & 14 & 15 & 93 \\
\hline 4 & Momordica foetida & Rabies \&Gonorrhea & 11 & 12 & 92 \\
\hline 5 & Pappea capensis & External injuries and snake bite & 16 & 19 & 84 \\
\hline 6 & Rhus vulgaris & Dermatological diseases & 18 & 19 & 95 \\
\hline 7 & Schrebera alata & Dental, oral and pharyngeal & 13 & 15 & 87 \\
\hline 8 & Solanum incanum & Hepatitis and stomach ache & 17 & 20 & 85 \\
\hline 9 & Warburgia ugandensis & Tissue cancer and cold disease & 12 & 14 & 85 \\
\hline 10 & Withania somnifera & Evil spirit diseases & 10 & 12 & 83 \\
\hline
\end{tabular}

Legend: $\mathrm{FL}=$ Fidelity Level, $\mathrm{Np}=$ number of informants who independently cited the importance of a species for treating a particular disease, $\mathrm{N}=$ total number of informants who reported the plant for any given disease

\section{Medicinal use values of selected plant species}

Traditional medicinal uses of different medicinal plant species against several human ailments were compiled. Investigation of their use-value indicated that some of these plants show high medicinal usevalue (UVmed) as indicated in Table 7.

Table 7. Medicinal use values (UVmed) of most-cited human medicinal plants in Suro Barguda District 


\begin{tabular}{|lccccc|}
\hline $\begin{array}{l}\text { Medicinal plant } \\
\text { species }\end{array}$ & $\begin{array}{l}\text { No. informants citing the } \\
\text { species }\end{array}$ & 81 & $\begin{array}{l}\text { Total } \\
\text { citations }\end{array}$ & $\begin{array}{l}\text { No. of ailments } \\
\text { treated with }\end{array}$ & UVmed. \\
\hline $\begin{array}{l}\text { Asparagus } \\
\text { africanus }\end{array}$ & 118 & 605 & 5 & 7.4 \\
\hline $\begin{array}{l}\text { Capparis } \\
\text { tomentosa }\end{array}$ & 92 & 980 & 5 & 8.3 \\
\hline $\begin{array}{l}\text { Cucumis } \\
\text { pustulatus }\end{array}$ & 60 & 589 & 4 & 6.4 \\
\hline $\begin{array}{l}\text { Euclea divinorum } \\
\text { Ehretia cymosa }\end{array}$ & 120 & 402 & 7 & 6.7 \\
\hline Pappea capensis & 140 & 912 & 8 & 8.6 \\
\hline Premna schimperi & 104 & 1232 & 6 & 6.5 \\
\hline
\end{tabular}

\section{Identification of multipurpose medicinal plants for their conservation priority}

The result of the direct matrix ranking exercise on the selected medicinal plants used for treating human ailments enabled us to identify which of the multipurpose plants was under greater pressure than other species in the area besides the respective factors that threaten the plants (Table 8).

Table 8. Average direct matrix ranking score of ten key informants for ten medicinal plant species with additional uses 


\begin{tabular}{|c|c|c|c|c|c|c|c|}
\hline \multirow[t]{2}{*}{ Medicinal plant species } & \multirow[b]{2}{*}{ Ch } & \multicolumn{4}{|c|}{ Use categories } & \multirow[t]{2}{*}{ Total } & \multirow[t]{2}{*}{ Rank } \\
\hline & & Co & Fr \&TI & Fw & Md & & \\
\hline Allophylus abyssinicus & 5 & 3 & 2 & 3 & 2 & 15 & $4^{\text {th }}$ \\
\hline Combretum molle & 1 & 3 & 3 & 4 & 3 & 14 & $5^{\text {th }}$ \\
\hline Ehretia cymosa & 2 & 1 & 2 & 3 & 1 & 9 & $10^{\text {th }}$ \\
\hline Fagaropsis angolensis & 3 & 3 & 4 & 5 & 3 & 18 & $2^{\text {nd }}$ \\
\hline Olea europaea subsp. cuspidata & 3 & 5 & 2 & 4 & 2 & 16 & $3^{\text {rd }}$ \\
\hline Pappea capensis & 3 & 3 & 2 & 2 & 1 & 11 & $8^{\text {th }}$ \\
\hline Podocarpus falcatus & 1 & 2 & 1 & 4 & 2 & 10 & $9^{\text {th }}$ \\
\hline Schrebera alata & 1 & 3 & 3 & 3 & 2 & 12 & $7^{\text {th }}$ \\
\hline Terminalia brownii & 3 & 2 & 2 & 4 & 2 & 13 & $6^{\text {th }}$ \\
\hline Warburgia ugandensis & 4 & 5 & 4 & 3 & 4 & 20 & $1^{\text {st }}$ \\
\hline Total & 26 & 30 & 25 & 35 & 22 & 138 & \\
\hline Rank & $3^{\text {rd }}$ & $2^{\text {nd }}$ & $4^{\text {th }}$ & $1^{\text {st }}$ & $5^{\text {th }}$ & & \\
\hline
\end{tabular}

Where $\mathrm{Ch}=$ Charcoal, $\mathrm{Co}=$ Construction, $\mathrm{Fr} \& \mathrm{TI}=$ Furniture and Tools, $\mathrm{Fw}=$ Firewood and

Md = Medicinal.

N.B. Scores in the table indicate ranks given to medicinal plants based on their use diversity. The highest number (5) given for the medicinal plant which informants thought was used commonly for the mentioned purpose and the lowest number (1) for the least needed for that purpose.

\section{Use diversity of medicinal plants}

All the 98 medicinal plant species recorded for human ailments treatment in the district were cited for one or more uses other than their medicinal role. The proportion of medicinal plant species over different use categories was summarized in Figure 5.

Figure 5. The proportion of human medicinal plants over different use categories

\section{Solvent and additives used in traditional herbal medicines prepared in the study area}

Almost in all ethno formulations of traditional medicines, water served as 'solvent' whenever dilution is required. Different additives were incorporated in $23.4 \%$ of the whole ethno formulations and "Magado" 
salt (locally produced salt) was the most commonly used additive (Figure 6).

\section{Distribution of indigenous knowledge on medicinal plants among different social groups in the community of the study area}

The difference in naming medicinal plants between different social groups (elders, youngsters, male, female, literate, illiterate, key informants, randomly taken informants, etc.) was analyzed by using a statistical test as follows (Table 9).

Table 9. Statistical test of significance on the average number of medicinal plants among different informant groups in Suro Barguda District

\begin{tabular}{|c|c|c|c|c|c|}
\hline Considerations & Informant groups & $\mathbf{N}$ & $\begin{array}{l}\text { Average } \pm \\
\text { SD }\end{array}$ & $\begin{array}{l}\mathrm{t}- \\
\text { value }\end{array}$ & $\begin{array}{l}\mathrm{p}- \\
\text { value }\end{array}$ \\
\hline \multirow[t]{2}{*}{ Gender } & Males & 290 & $2.65^{6.62 \pm}$ & \multirow[t]{2}{*}{1.97} & \multirow[t]{2}{*}{0.97} \\
\hline & Females & 102 & $2.18^{6.05 \pm}$ & & \\
\hline \multirow[t]{2}{*}{ Age } & Youngsters & 208 & $2.07^{5.16 \pm}$ & \multirow[t]{2}{*}{-12.87} & \multirow[t]{2}{*}{$0.00 *$} \\
\hline & Elders & 184 & $2.19^{7.96 \pm}$ & & \\
\hline \multirow[t]{2}{*}{ Literacy } & Illiterates & 292 & $2.31^{7.22 \pm}$ & \multirow[t]{2}{*}{12.92} & \multirow[t]{2}{*}{$0.00 *$} \\
\hline & Literates & 100 & $1.82^{4.28 \pm}$ & & \\
\hline \multirow[t]{2}{*}{$\begin{array}{l}\text { Proximity to the health } \\
\text { center }\end{array}$} & Near to health center & 22 & $2.37^{6.00 \pm}$ & \multirow[t]{2}{*}{-0.94} & \multirow[t]{2}{*}{0.36} \\
\hline & $\begin{array}{l}\text { Far away from the health } \\
\text { center }\end{array}$ & 370 & $2.57^{6.5 \pm}$ & & \\
\hline \multirow{2}{*}{$\begin{array}{l}\text { Informant } \\
\text { category }\end{array}$} & Key informants & 50 & $\begin{array}{l}10.76 \pm \\
1.09\end{array}$ & \multirow[t]{2}{*}{25.75} & \multirow[t]{2}{*}{$0.00 *$} \\
\hline & $\begin{array}{l}\text { Randomly taken } \\
\text { informants }\end{array}$ & 342 & $2.04^{5.85 \pm}$ & & \\
\hline
\end{tabular}

*Significant difference $(p<0.05)$; ** $t(0.05)$ (two tailed), degree of freedom $(d f)=223$,

$\mathrm{N}=$ number of respondents

\section{Market survey of medicinal plants}


A market survey was done in the biggest market of the district (Suro Market) to observe and collect data on the marketability and trade of medicinal plants. The researchers observed as some medicinal plants were sold for other purposes than their medicinal use?

\section{Discussion}

In Suro Barguda District large number of medicinal plants were reported which were used to treat human ailments and the finding indicated the presence of considerable diversity of plant species. Of the 98 collected medicinal plant species, Fabaceae contributed ten species $(10.2 \%)$ followed by Lamiaceae which donated seven species (7.1\%). This could be due to the dominant presence of Fabaceae, Asteraceae, and Lamiaceae families in the flora of Ethiopia and Eretria [24, 25, 26]. The existence and utilization of such a large number of medicinal plants might indicate that the majority of the people continue to employ indigenous medicinal practices to date. Four of the medicinal plants which were used to treat human ailments were endemic to Ethiopia. Identified growth forms of medicinal plants indicated that shrubs were more dominant $(36 ; 36.7 \%)$ which was in agreement with other studies in Ethiopia such as $[27,28,29,30,31,32]$ followed by trees $(30 ; 30.6 \%)$ and herbs $(14 ; 14.3 \%)$. This could be due to the high occurrence and impact tolerance capacity of shrubs in the study area. Almost all of the medicinal plants were obtained from the wild. But, the wild habitats were highly depleted due to an increased human and livestock population which resulted in the loss of many medicinal plant species growing in the wild. This finding was in agreement with reports of almost all other studies on wild habitats for harvesting an ample of medicinal plants such as $[33,34,35,36]$.

\section{Parts of medicinal plants used for remedy preparation}

A variety of plant parts were reported as to be used for remedial preparation in the district but about $36.2 \%$ of the preparations were obtained from leaves which was also commonly reported by other ethnomedicinal studies elsewhere in Ethiopia, [32, 34, 37, 38, 39] followed by roots $(23.8 \%)$ and barks (18.6\%). In addition to this the leaves, barks, and roots were used in different preparations in mixture with other plant parts in the district. The higher usage of leaves in traditional remedy preparations could partly be due to its easy availability and the usage of roots in the second place could be because these parts remain in the soil which enables them to be taken at any time even during the long dry season especially in arid and semi-arid areas like the present study area. Assumed the highest frequency of leaves used for medicinal purposes in the study area threat to the destruction of medicinal plants especially to trees and shrubs was found to be minimal, as high threat to the mother plant comes with root, bark, and leafy-stem harvests (especially roots affect the survival of the plant since aerial parts of the plant are highly dependent on it for physiological processes and physical support as these parts are the second most frequently used parts in the study area). However, [40] indicated that the harvest of leaves has also a threat to the deterioration of medicinal plants since the removal of leaves limits the transformation of vegetative to reproductive development such as flower production and fruit/seed set, which in its turn limits the natural/wild regeneration of plants. According to [41] medicinal plant harvests that mainly involve roots, stems and barks have a serious effect on the survival of mother plants. Most of the remedy 
preparation was reported from freshly collected plant parts (93.7\%). Using freshly harvested medicinal plant parts could be due to the belief that this form could attain high efficacy since it could contain higher bioactive ingredients (curative elements, a knowledge which could be obtained from long and repeated experience). [42] had declared that the uses of fresh medicinal plants were more effective than other parts. The reliance of local people on fresh materials in the study area including the usage of fresh barks and leaves put the plants under serious threat than the dried form, as fresh materials are collected directly and used soon with its extra corrosion with no chance of preservation i.e. not stored for later use. This finding was also in line with other ethnomedicinal studies elsewhere in the country $[33,39,41,43]$ whereas dried parts were used least and a certain amount of remedies was reported to be prepared both from dried or fresh parts of medicinal plant species.

\section{Types of disease, medicine preparations, and treatment methods}

Fifty-nine disease types, affecting humans, were identified in Suro Barguda District to be treated with traditional medicines (Appendix 1). Out of the major disease categories in the study area, Gastrointestinal diseases such as toothache, stomach ache, and diarrhea were the most frequently reported human ailments mainly treated traditionally using a large number of medicinal plants. This may be due to the spreading of various pathogens as a result of less hygiene and control measures in such rural areas. This could also validate the effort of local healers in probing out more and suitable medicinal plant species for the treatment of such diseases. Similar research findings were reported by [44]. These diseases were diagnosed commonly through interview and visual inspection of the patients before any herbal medicine administration. Similar reports were made by $[33,45,46]$. Once the healer gets the required information herbal medicines would be prepared and administered following the proper route and the type of disease. The major mode of herbal medicine preparation for human ailments was chopping or pounding and homogenizing it with cold water, findings which were similar to the reports of [39]. This was followed by crushing and put on plant parts and chopping, homogenizing, and boiling plant parts. The oral application was the most common route of administration $(70.4 \%)$, a report similar to $[33,36]$ which was followed by dermal and nasal administrations. Other remedies were reported to be administered through a deep opening on the body formed due to infection "Luxaa - in local Guji Oromo language", aural and ocular routes concerning the type of ailment reported during diagnosing the patient. It was reported that determination of remedies dose for various ailments was based on physical appearance, age, and gender of the patient (no standardized measurements) except determining it based on the long term experiences of traditional healers. Similar findings were reported in other parts of the country $[43,47]$. Remedies were reported to be measured in coffee cups, water glasses, liters while others were measured with the tip of fingers or pieces of particles. As said by [15] lack of standardization and precision has been a global shortcoming of the traditional healthcare system. Using additives in traditional remedies preparation is for different purposes (either to increase the healing potential or to improve the flavor and taste or to avoid abdominal discomfort) [31, 48]. Milk, yogurt, honey, and coffee were mentioned as antidotes for traditional medicines with adverse side effects such as vomiting, diarrhea, and feeling of burning and sometimes weakening of the patient. Similar findings were reported by $[43,49,50]$. Patients with gastrointestinal problems, venereal diseases, malaria, hepatitis, hypertension, diabetics, TB, rabies, 
poisons, etc. were commonly reported to be treated with liquid preparations or chewable plant parts given orally. This finding was in agreement with reports of [47]. Those with different skin diseases and tissue cancer were reported to be treated with crushed or chewed preparations through rubbing or pasting herbal preparations. Diseases such as febrile illness, headache, evil eye, etc. were reported to be treated either through fumigation or washing the patient with liquid herbal preparations. Culture, efficacy, availability, and economic factors were reported as the key factors which lead the community to use traditional medicines other than modern healthcare systems with their unaffordable high prices and unavailability. These findings were in agreement with the findings of $[33,51]$.

\section{The most preferred plants for treating human ailments}

The output of preference ranking exercise on medicinal plants that were reported to be used against toothache showed that Clerodendrum myricoides was the most preferred species followed by Scherebra alata and Carissa spinarum. This indicated that indigenous people of the study area had sufficient knowledge on the healing potential of medicinal plants for different diseases. Consensuses on most frequently used medicinal plants indicated that Justicia schimperiana and Warburgia ugandensis were well-known medicinal plants in the study area in treating hepatitis and internal organ cancer respectively. Informant consensus means agreement among informants. Selecting traditional medicinal plants by using informant consensus was used to evaluate the reliability of the data. Among the twelve categorized human ailments, the highest informant consensus factor value (ICF value) was for breathing system diseases for its frequent occurrence. High ICF values are important to name plants of particular interest in the search for bioactive compounds [7]. The highest plant use citation was seen for Gastrointestinal diseases. The observed high informant agreement together with high plant use citations for these disease categories could also indicate the relatively high occurrence of the diseases in the area (about 16 medicinal plant species were cited for treating Gastrointestinal disease categories).

\section{The relative healing potential of medicinal plants used for treating human ailments}

The highest fidelity level value was recorded for Combretum molle in treating the gastro-intestinal disease therapeutic category which was followed by Fagaropsis angolensis used to treat breathing system diseases. These values could be a clue for the high healing potential of these plants against the corresponding diseases. An informant consensus factor (ICF) value was used to evaluate the reliability of the data and these values were computed based on the reported medicinal plant species and their use citations. [52] stated that plants scoring higher informant consensus values are thought to have better potency having biologically active ingredients in treatment as compared to plants with less informant consensus values. In this analysis, the use citation for medicinal plants used to treat gastrointestinal diseases was higher (92\%). In this study, informant consensus factor values (ICF values) were used to identify the harmony of the informants on the reported cure for the group of ailments (gastrointestinal diseases) of the plant while fidelity level (FL) computes the significance of a species (Combretum molle) to treat a given disease (gastrointestinal diseases). Hence, their analyses values inveterate as the information obtained was real. 


\section{Use diversity of medicinal plants}

Medicinal plant species recorded for human ailments treatment in the district were cited for one or more uses other than their medicinal role. All medicinal plant species were considered useful for environmental services such as control of erosion, soil improvement, being food and shelter for wild animals, and balancing climatic conditions which is the general truth with no compromise. The dominance of plants cited for environmental services was proper from the standpoint that every plant species has its role in maintaining balanced biophysical systems. About 55 woody medicinal plant species of the district were used as fuel (charcoal and firewood) for the local people and 48 medicinal plant species were cited for additional uses as fodder indicating their supplementary role in supporting the livestock wealth of the district, on which most people depend for their livelihoods. Others such as 30 medicinal plant species were reported for construction and material making, 22 medicinal plant species were cited as wild edible plants, five medicinal plant species were indicated as plants giving social services, and two medicinal plant species were reported as being poisonous. These results indicated how much the indigenous knowledge of the local people was used in using plant resources for different purposes to ensure their existence through fulfilling their requirements. On the other hand, the highest proportion of plant species used across different use categories reflects the relative importance of different plant species in people's daily life [53].

\section{Identification of multipurpose medicinal plants for their conservation priority}

The indigenous religion of Guji Oromo (Waaqeffannaa) has a positive contribution to natural resource management. In this indigenous belief cutting big trees is out of bounds, because when it falls it has very huge sound and power which would disturb God (Waaqa) and all humans closer to the area as well. Big trees are respected like big elders in Guji Oromo. Forests have appealing value and certain early ancestral historical bonds with the community. Due to disturbed climatic conditions, minimized agricultural production, and economic crisis the care for natural resources is minimizing now a day. Several studies also indicated $[45,54,55]$ that increase in human and livestock population, as well as growing investment in agriculture, became the major threat for the deterioration of vegetation in general and medicinal plants in particular. The study by [55] also indicated that the use of firewood and construction, as well as agricultural expansion, were the main causes for the diminution of medicinal plants in the study area. Direct matrix ranking exercise for ten selected multipurpose medicinal plants in five use diversities (charcoal, construction, furniture, and tools, firewood and medicinal) indicated that Warburgia ugandensis was ranked first (most - threatened) which is followed by Fagaropsis angolensis and Olea europaea subsp. cuspidata. Since stem bark of Warburgia ugandensis was highly and unwisely used in treating different diseases in Guji Oromo traditional medication its population was reaching nearly zero (lost through drying) with the effect of disturbances (grazing, browsing, and selective cutting) which seriously affect the emergence of seedlings and their growth to saplings. In the same way, poor reproduction ability, selective cutting mostly for construction purposes, overgrazing, and browsing affect the existence of Fagaropsis angolensis. Even if Olea europaea subsp. cuspidata has good reproduction ability, stable population structure and good regeneration status, cutting of bigger individuals for firewood 
and the destruction of seedlings and saplings due to overgrazing and browsing this plant was highly affected. Therefore, the output of this study indicated that these multi-purpose medicinal plant species were currently exploited more for their non-medicinal uses such as for firewood, construction, and charcoal production. Hence, these findings reflected the requirement of an urgent harmonizing conservation action to save the fast-eroding multipurpose medicinal plant species of the study area. [51] had also reported the same pattern of high exploitation of multipurpose medicinal plants.

\section{Distribution of indigenous knowledge on medicinal plants among different social groups in the community of the study area}

Although more medicinal plants were reported by men (290) than women (102), the difference was not significant $(P>0.05)$ when the average number of medicinal plants mentioned by each group was compared. There was no significant difference seen in the number of medicinal plants listed by informants living around health centers and those living relatively far away from these health centers. However, there was a significant difference $(P<0.05)$ in the number of medicinal plants reported by senior members of the community ( $>40$ years old) and young- to middle-aged members ( $<40$ years old); key informants and randomly taken informants, illiterate and literate informants (Table 34). More number of medicinal plants was reported by elders ( $>40$ years old), illiterates, and key informants than by young, literates, and randomly taken informants. Deteriorating a positive attitude towards the use of traditional medicine by young generations indicates the loss of the main indigenous knowledge. [56] in Cameon indicated in his study that most young people in urban areas were not interested in the use of traditional medicine due to the effect of western culture; the manner in mind that traditional medicine is credulous, which is mainly used by deprived and illiterate people. Alternatively, most of the elders kept their knowledge secret in thinking of the medicine become ineffective if it is told to everybody. Likewise, the decline of the traditional knowledge in the generation is due to the intrusion of and shifts to the use of more artificial drugs not only in the urban but also extending to the countryside. Numerous studies indicated that lack of formal education in traditional knowledge in developing nations is another factor for the weakening of indigenous knowledge [57, 58]. Because there was no way of documenting and transfer it to the next generation. Furthermore, most of the African contemporary health professionals significantly emasculate the contribution of traditional medicine in the health care system however the scientists of developed nations exhaustively search for medicinal plants to search for a solution for the hoary and newly rising diseases especially viral diseases. All these factors may result in a loss of this precious and useful knowledge that has been accumulated over many generations.

\section{Marketability of medicinal plants}

The finding from the market survey of medicinal plants indicated that in the culture of Guji Oromo (an ethnic group of the study area) it is forbidden to sell traditional medicine in the market. Even if people coming from other areas usually sell them, the local people didn't accept it. When traditional healers cure a patient they will be compensated by giving some things in kinds such as a certain amount of dried and pounded tobacco, coffee with salt or sugar, and if it is a critical disease a goat or heifer not money as the 
cultural rule permits. Sometimes the cured person returns the favor by inviting the healer and his family overnight in his house. This cultural trend might cause the local healers, not to sell traditional medicines in the market which was confirmed by the market survey (Suro Market). But some traditional medicinal plants can be sold for other purposes such as Combretum molle, Olea europaea subsp. cuspidata and Osyris quadripartita for fumigation in producing good odor and feeling for the body, milk containers, and the house.

\section{Conclusion}

The study area was rich in having medicinal plants and corresponding indigenous knowledge diversity. Findings of this study indicated that there was higher usage of leaves of most medicinal plants to prepare various traditional remedies. Even though collecting these parts seems not harming much the regular physiological activities of the plant, those plants only with a limited number of leaves can be endangered unless proper consideration is given. Hence, conservation work in the area needs to give prior attention to protect such types of plant species. Traditional practitioners diagnose their patients through observation and asking the patient about the feelings of the disease and then prepare the medicine to administer it accordingly based on their cultural knowledge on symptoms, corresponding illnesses, and therapeutic medicinal species held in the knowledge of indigenous people. This may be more effective if these people obtain certain training from modern health professionals about how to identify some diseases based on their symptoms especially those which are easily communicable to minimize the possible severe problems that could happen in the local community and how to determine the doses of the preparations.

Traditional practitioners showed varying degrees of traditional medicinal plant use knowledge based on differences in age, experience, gender, and education level. More ethnomedicinal knowledge was observed in elderly members of the community than in younger groups; experienced/key practitioners than the general public; and more with the illiterate than the literate. Because of the cultural norm and secrecy of the traditional medication system, this knowledge was transmitted along the selected male line of the family members due to which males could be more knowledgeable than females even if the difference in knowledge concerning gender was not exaggerated in the study area. Oral transmission of traditional knowledge and its flow only through the selected male line of the family for its secrecy may cause it to be depleted soon for modernization and ignorance of the new generation. High ICF, FL, and medicinal use values testing exercises result showed that the selected medicinal plants of Suro Barguda District had promising bioactivity elements. These findings were in line with the fourth hypothesis of this research which proposed "the traditional herbalists in the community were knowledgeable about healing plants, their preparation, and applications."

\section{Recommendations}

Plants afford a great economic and social value for the rural communities living as semi- pastoralists being used as forage and medicine for their livestock, source of both timber and other non-timber 
products as well as regulators of climatic conditions. Therefore, to ease the present human influence on the natural vegetation and for its future management on a sustainable basis in the district, the following recommendations are forwarded:

- Raising public awareness, through extension programs, on the multiple uses of plant resources to safeguard the plant diversity;

- Most of the medicinal plants of the study area were found to play a multipurpose role across different use categories and consequently, some were under serious pressure challenging their survival. Hence, recorded high use value indices of multipurpose plant species in the study area could be used as signals of high use pressure and could be used as keys to design and implement well-coordinated complementary in situ and ex situ conservation activity to save these widely used plant species.

- Conservation action should be followed with close follow up about its sustainability not to be affected by resources used for different needs;

- In natural resource conservation such as regional or national protected areas, giving responsibility and sense of ownership to the local community so that they assume it as their property and they will manage and conserve it to become beneficiaries of the economic payback that can be obtained from this action;

- Conservationists should set up medicinal plant nursery sites in co-operation with the District's Agriculture and Rural Development Office to propagate seedlings of the most-preferred medicinal plants, followed by a parallel distribution of seedlings to the local community as a possible means of reducing pressure on natural stands and conserve useful medicinal plant species;

- The indigenous knowledge of pastoralists about plants (a traditional system of rangeland management) and livestock (breeding different species of livestock (grazers with browsers), as well as their environmental management system (traditional forest, soil, and water conservation system), should be incorporated in the planning and implementation of developmental interventions;

- Carefully designed community-based and participatory approaches are recommended to control bush encroachment through minimizing deforestation, overgrazing, and raising awareness of the local community to use controlled burning by clearing unwanted bushes;

- Medicinal plants such as Warburgia ugandensis and Fagaropsis angolensis should be given conservation priority for their multipurpose uses;

- Conservation measures which might be designed for vegetation resources of Suro Barguda District by policymakers, natural resource managers, or stakeholders would need to take into account special protection and monitoring of the endemic taxa as well as the most important useful plant species found in the vegetation;

- Good effort should be made by stakeholders to close the observed generation gap in indigenous knowledge ( $\mathrm{b} / \mathrm{n}$ elders and youngsters) through uninterrupted professional support and training of local communities to preserve their traditional knowledge and practices through systematic documentation; 
- The efficacy of the preparations, techniques, and practices need to be investigated to identify promising plants for use in livestock development plans. So, bioactive chemicals of Croton macrostachyus and Pappea capensis should be screened out in scientific works for their pharmacological potentials because they were used to treat different human diseases.

\section{Declarations}

\section{Acknowledgment}

We would like to thank Bule Hora University; Governmental Officials, societal leaders, and the local community of Suro Barguda District for their full cooperation in adjusting favorable conditions for gathering the data and effectiveness of this original research.

\section{Authors' contributions}

Dr. Mersha Ashagre Eshete carried out fieldwork, collected and analyzed the data, and wrote the manuscript. Dr. Ermias Lulekal Molla critically reviewed and improved the first draft of the manuscript. The two authors have read and approved the final version of the manuscript.

\section{Funding}

As one of the three main tasks of all university instructors (Teaching, providing community service, and carrying out research), this research was funded by Bule Hora University Research and Community Service V/P Office to glean out indigenous knowledge of the local community and disclose it for the whole world through publishing the research output on the reputable journal, of which this publisher is the one.

\section{Ethics approval and consent to participate}

This ethnobotanical study of medicinal plants used to treat human ailments was approved by the concerned bodies of Bule Hora University. During our field investigations, all stakeholders in this study, including users of traditional medicines, the local community of Suro Barguda District, and all authors willingly agreed to participate in the study, use the data related to their knowledge and publish the results.

\section{Consent for publication}

Consent for publication has been obtained from the Scientific Research Committee of the Bule Hora University, College of Natural and Computational Sciences, authors, and all stakeholders who participated in this study.

\section{Competing interests}

The authors declare that they have no competing interests. 


\section{References}

1. Martin, G. Ethnobotany: A method Manual. Chapman and Hall, London, 1995.

2. Balick, M. and Cox, P. Plants, People, and Culture: Science of Ethnobotany. Scientific American Library, New York, USA. 1996.

3. Cotton, C. Ethnobotany: Principles and Applications. John Wiley and Sons, New York, 1996.

4. Nakashima, D. and Rou'e, M. Indigenous Knowledge, Peoples and Sustainable Practice; In: Encyclopedia of Global Environmental Change, Social and economic dimensions of global environmental change, 2002, Volume 5, pp 314-324.

5. Tessema Tanto, Mirutse Giday, Negusu Aklilu and Teshome Hunduma. Medicinal Plants Biodiversity. National Biodiversity Strategy and Action Plan (NBSAP) Project. Institute of Biodiversity Conservation and Research (IBCR), Addis Ababa, Ethiopia, 2003.

6. Tilahun Teklehaymanot and Mirutse Giday. Ethnobotanical study of medicinal plants used by people in Zegie peninsula, northwestern Ethiopia. Journal of Ethnobiology and Ethnomedicine, 2007, 3: 12.

7. Mwambazi, W. WHO partnership in the development and utilization of herbal remedies in Ethiopia. In: Abebe D. ed. Proceedings of the workshop on development and utilization of herbal remedies in Ethiopia. 1996 June 4-6; Addis Ababa: EHNRI: 26-27.

8. Kebede Deribe, Alemayehu Amberbir, Binyam Getachew and Yunis Mussema. A historical overview of traditional medicine practices and policy in Ethiopia. Ethiopian Journal of Health Development, 2006, 20, 127-134.

9. Pankhurst, R. An Introduction to the Medical History of Ethiopia. The Red Sea Press, INC, Trenton, New Jersey, 1990.

10. Pankhurst, R. An historical examination of traditional Ethiopian medicine and surgery. Ethiopia Medical Journal, 1965, 3, 157-172.

11. Slikkerveer, L. Plural Medical Systems in the Horn of Africa: The Legacy of "Sheik" Hippocrates. Kegan-Paul International, London, \& New York, 1990.

12. Dawit Abebe and Ahadu Ayehu. Medicinal plants and Enigmatic Health practice of Northern Ethiopia, BPE, Addis Ababa, 1993.

13. Gadgil, M., Bekes, F. and Folke, C. Indigenous knowledge for biodiversity conservation. Ambio: Journal of the Human Environment, 1993, 22: 151 - 156.

14. Turner, N. Ethnobotany: Future direction for the new millennium. Manitoba Anthropology Student's Journal, 2000, 16:15 - 18.

15. Dawit Abebe. The role of medicinal plants in healthcare coverage of Ethiopia, the possible benefits of integration. In: Proceedings of Workshop on Biodiversity Conservation and Sustainable Use of Medicinal Plants in Ethiopia, Medhin Zewdu, 191 Abebe Demissie (eds), Institute of Biodiversity Conservation and Research, Addis Ababa, Ethiopia, 28 April -May 2001, pp. 6-21.

16. Bartlett, J., Kotrlik, J., and Higgins, C. Organizational research: Determining appropriate sample size for survey research. Journal of Information Technology, Learning, and Performance, 2001; 19(1):43- 
50.

17. Cunningham, A. African medicinal plants, setting priorities at the interface between conservation and primary healthcare. People and plants working paper 1; 1993, Paris, France: UNESCO.

18. Höft, M., Barik, S. and Lykke, A. Quantitative ethnobotany. Applications of multivariate and statistical analysis in ethnobotany. Peoples and plants working paper 6. UNESCO. Paris, France, 1999.

19. Hoffman, B. and Gallaher, T. Important indices in ethnobotany. Ethnobotany Res Appl. 2007, 5:20118.

20. Heinrich, M. Ethnobotany and its role in drug development. Phytother Res. 2000;14:479-88.

21. Alexiades, M. Collecting Ethnobotanical Data. An Introduction to Basic Concepts and Techniques. In: Selected Guidelines for Ethnobotanical Research: A Field Manual, Alexiades, M. N. and Sheldon, J. W. (eds.), 1996. The New York Botanical Garden, Bronx, New York, pp. 53-94.

22. Heinrich, M., Ankli, A., Frei, B., Weimann, C. and Sticher, O. Medicinal plants in Mexico: Healers' consensus and cultural importance. Social Science and Medicine, 1998, 47:1859-1871.

23. Phillips, O. and Gentry, A. The useful plants of Tambopata, Peru: I. Statistical hypotheses tests with a new quantitative technique. Economic Botany, 1993, 47:15-32.

24. Flora of Ethiopia and Eritrea: Gentianaceae to Cyclocheilaceae; Volume 5. Edited by Hedberg I, Kelbessa E, Edwards S, Demissew S, Persson E. Uppsala Sweden: Addis Ababa, Ethiopia, and Department of Systematic Botany; 2006.

25. Flora of Ethiopia and Eritrea: Canellaceae to Euphorbiaceae; Volume 2. Edited by Edwards S, Tadesse M, Hedberg I. Uppsala Sweden: Addis Ababa, Ethiopia, and Department of Systematic Botany; 1995.

26. Flora of Ethiopia and Eritrea: Asteraceae; Volume 4, part 2. Edited by Hedberg I, Friis I, Edwards S. Uppsala, Sweden: Addis Ababa, Ethiopia, and Department of Systematic Botany; 2004.

27. Alemayehu Kefalew, Zemede Asfaw and Ensermu Kelbessa. Ethnobotany of medicinal plants in Ada'a District, East Shewa Zone of Oromia Regional State, Ethiopia. Journal of Ethnobiology and Ethnomedicine, 2015; 11:25.

28. Anteneh Belayneh, Zemede Asfaw, Sebsebe Demissew and Negussie Bussa. Medicinal plants potential and use by pastoral and agro-pastoral communities in Erer Valley of Babile Wereda, Eastern Ethiopia. Journal of Ethnobiology and Ethnomedicine, 2012, 8:42.

29. Bayafers Tamene. A Floristic Analysis and Ethnobotanical Study of the Semi-Wetland of Cheffa Area, South Wello, Ethiopia. M.Sc.Thesis,AddisAbabaUniversity,Addis Ababa, 2000.

30. Debela Hunde, Zemede Asfaw and Ensermu Kelbessa. Use of traditional medicinal plants by people of 'Boosat' sub-district, Central-Eastern Ethiopia. Ethiopian Journal of Health Sciences, 2006, 16(2):141-155.

31. Kebu Balemie, Ensermu Kelbessa, and Zemede Asfaw. Indigenous medicinal plant utilization, management and threats in Fentalle area, Eastern Shewa, Ethiopia. Ethiop. J. Biol. Sci. 2004, 3 (1): $37-58$. 
32. Mersha Ashagre, Ensermu Kelbessa and Gemedo Dalle. Ethnobotanical study of medicinal plants in Guji Agro-pastoralists, Bule Hora District of Borana Zone, Oromia Region, Ethiopia. Journal of Medicinal Plants Studies, 2016, 4(2): 170-184.

33. Fisseha Mesfin, Sebsebe Demissew and Tilahun Tekelaymanot. An Ethnobotanical study of medicinal plants in Wonago Woreda, SNNPR, Ethiopia. Journal of Ethnobiology and Ethnomedicine, 2009, 5:28.

34. Getaneh Gebeyehu, Zemede Asfaw, Abiyu Enyew, and Nagappan, R. Ethnobotanical study of traditional medicinal plants and their conservation status in Mecha Wereda, West Gojjam zone of Ethiopia; Int. J. Pharm. and H. Care Res. 2014, Vol. - 02(03), 137 - 154.

35. Solomon Araya, Balcha Abera, and Mirutse Giday. Study of plants traditionally used in public and animal health management in Seharti Samre District, Southern Tigray, Ethiopia. Journal of Ethnobiology and Ethnomedicine, 2015, 11:22.

36. Teferi Flatie, Teferi Gedif, Kaleab Asres, and Tsige Gebre-Mariam. Ethnomedical survey of Berta ethnic group Assosa Zone, Benishangul-Gumuz regional state, mid-west Ethiopia. Journal of Ethnobiology and Ethnomedicine, 2009, 5:14 doi: 10.1186/1746-4269-5-14.

37. Fisseha Mesfin, Talemos Seta, and Abreham Assefa. An Ethnobotanical Study of Medicinal Plants in Amaro Woreda, Ethiopia; Ethnobotany Research \& Applications, 2014, 12:341-354.

38. Getu Alemayehu, Zemede Asfaw, and Ensermu Kelbessa. Ethnobotanical study of medicinal plants used by local communities of Minjar-Shenkora District, North Shewa Zone of Amhara Region, Ethiopia. Journal of Medicinal Plants Studies, 2015, 3(6): 01-11.

39. Seyoum Getaneh and Zerihun Girma. An ethnobotanical study of medicinal plants in Debre Libanos Wereda, Central Ethiopia. African Journal of Plant Science, 2014, Vol. 8(7), pp. 366 - 379.

40. Cunningham, A. Applied Ethnobotany: People, Wild Plant Use and Conservation. The UK.Dev S.: Earthscan, London; 2001.

41. Ermias Lulekal, Ensermu Kelbessa, Tamrat Bekele and Haile Yineger. An ethnobotanical study of medicinal plants in Mana Angetu District, southeastern Ethiopia. Journal of Ethnobiology and Ethnomedicine, 2008a, 4:10.

42. Sofowara, A. Medicinal plants, and traditional plants in Africa. Chichester and New York; 1982.

43. Haile Yineger, Delenasaw Yewhalaw, and Demel Teketay. Ethnomedicinal plant knowledge and practice of the Oromo ethnic group in southwestern Ethiopia. Journal of Ethnobiology and Ethnomedicine, 2008a, 4:11.

44. Balcha Abera. Medicinal plants used in traditional medicine by Oromo people, Ghimbi District, Southwest Ethiopia; Journal of Ethnobiology and Ethnomedicine, 2014, 10:40.

45. Mirutse Giday, Zemede Asfaw, Thomas Elmqvist, and Zerihun Woldu. An ethnobotanical study of medicinal plants used by the Zay people in Ethiopia. Journal of Ethnopharmacology, 2003, 85: 4352.

46. Ermias Lulekal, Ensermu Kelbessa, Tamrat Bekele and Haile Yineger. Plant species composition and structure of the Mana Angetu moist montane forest, Southeastern Ethiopia. Journal of East African 
Natural History, 2008b, 97(2): 165-185.

47. Ketema Tolossa, Etana Debela, Spiridoula, A., Adugna Tolera, Gebeyehu Ganga, and Houdijk, J. Ethno-medicinal study of plants used for treatment of human, and livestock ailments by traditional healers in South Omo, Southern Ethiopia. Journal of Ethnobiology and Ethnomedicine, 2013, 9:32.

48. Temene, B. Floristic analysis and ethnobotanical study of the semi-wetland of Cheffa area South Welo. Ethiopia. M.Sc. Thesis: Addis Ababa University, Biology Department; 2002.

49. Ermias Lulekal, Zemede Asfaw, Ensermu Kelbessa, and van Damme, P. Ethnoveterinary plants of Ankober District, North Shewa Zone, Amhara Region, Ethiopia. J. Ethnobiol. Ethnomed, 2014, 4: 10.

50. Mirutse Giday, Zemede Asfaw, and Zerihun Woldu. Ethnomedicinal study of plants used in Sheko ethnic group of Ethiopia. Journal of Ethnopharmacology, 2010, 132:75-85.

51. Ermias Lulekal, Zemede Asfaw, Ensermu Kelbessa, and van Damme, P. Ethnomedicinal study of plants used for human ailments in Ankober District, North Shewa Zone, Amhara Region, Ethiopia. Journal of Ethnobiology and Ethnomedicine, 2013, 9: 63.

52. Trotter, R. and Logan, M. Informants consensus: a new approach for identifying potentially effective medicinal plants. In Plants in Indigenous Medicine and Diet. Edited by Etkin NL. New York: Redgrave Publishing Company, Bedford Hill; 1986:91-112.

53. Thomas, E. Quantitative Ethnobotanical Research on Knowledge and Use of Plants for Livelihood among Quechua, Yuracare, and Trinitario Communities in the Andes and Amazon regions of Bolivia. Ph.D. thesis, Ghent University, 2008.

54. Endeshaw Bekele. Study on the actual situation of medicinal plants in Ethiopia; 2007:54-60. http://www.endashaw.com.

55. Tolassa E. Use and management of medicinal plants in Ghimbi District. Southwest Ethiopia: MSc thesis, Addis Ababa University, Biology Department; 2007.

56. Simbo, D. An ethnobotanical survey of medicinal plants in Babungo, Northwest Region, Cameroon. $J$ Ethnobiol Ethnomed. 2010, 6:8-15.

57. Teshome W. Impacts of Urbanization on the Traditional Medicine of Ethiopia. Anthropologist 2005, 8:43-52.

58. Addis G., Abebe D., Genebo T. and Urga K. Perceptions and practices of modern and traditional health practitioners about traditional medicine in Shirka district, Arisi Zone. Ethiop J Health Dev. 2002, $16: 19-29$

\section{Tables}

Due to technical limitations, table 2 is only available as a download in the Supplemental Files section.

\section{Figures}




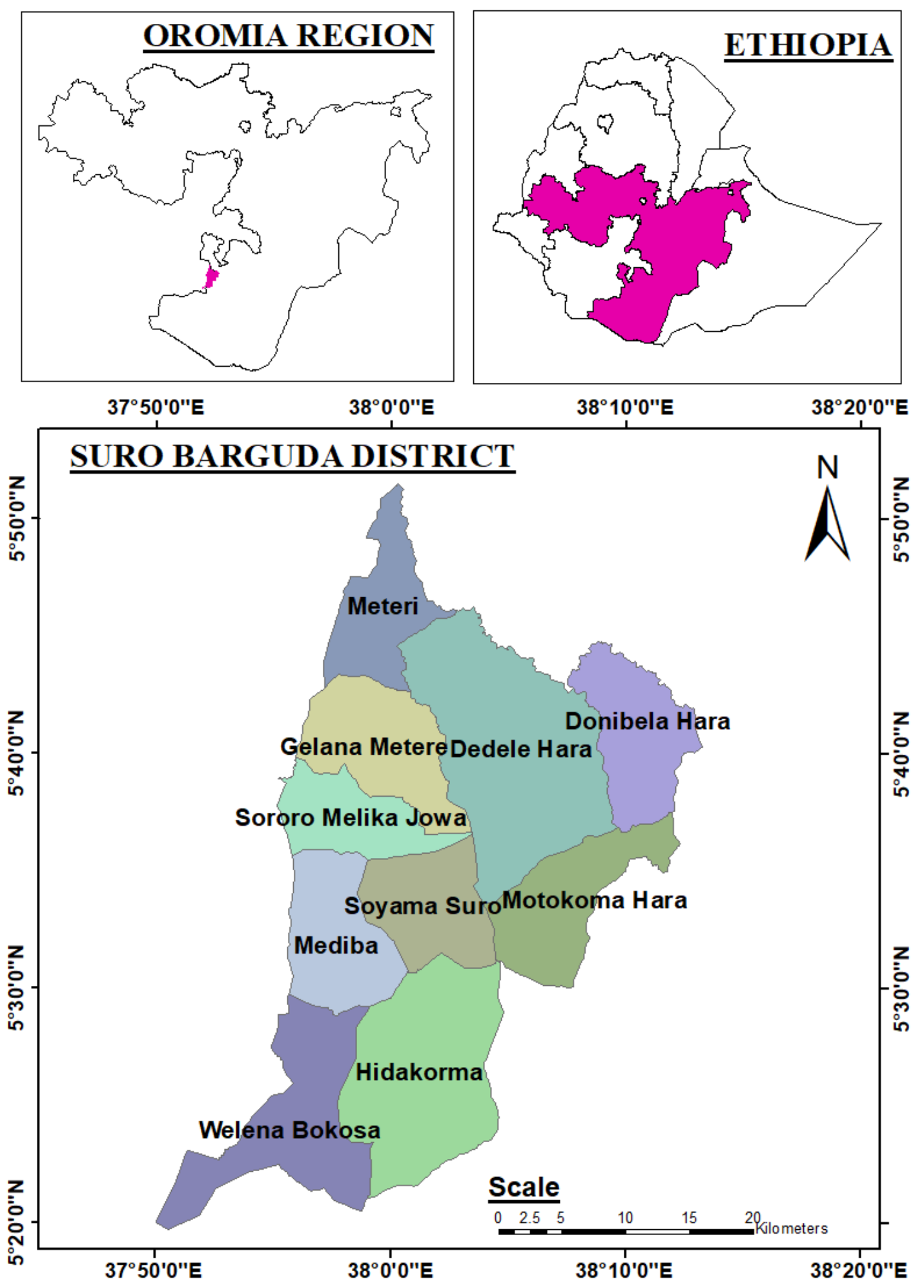

Figure 1

Map of Ethiopia showing Suro Barguda District (the study area) Note: The designations employed and the presentation of the material on this map do not imply the expression of any opinion whatsoever on the part of Research Square concerning the legal status of any country, territory, city or area or of its authorities, or concerning the delimitation of its frontiers or boundaries. This map has been provided by the authors. 


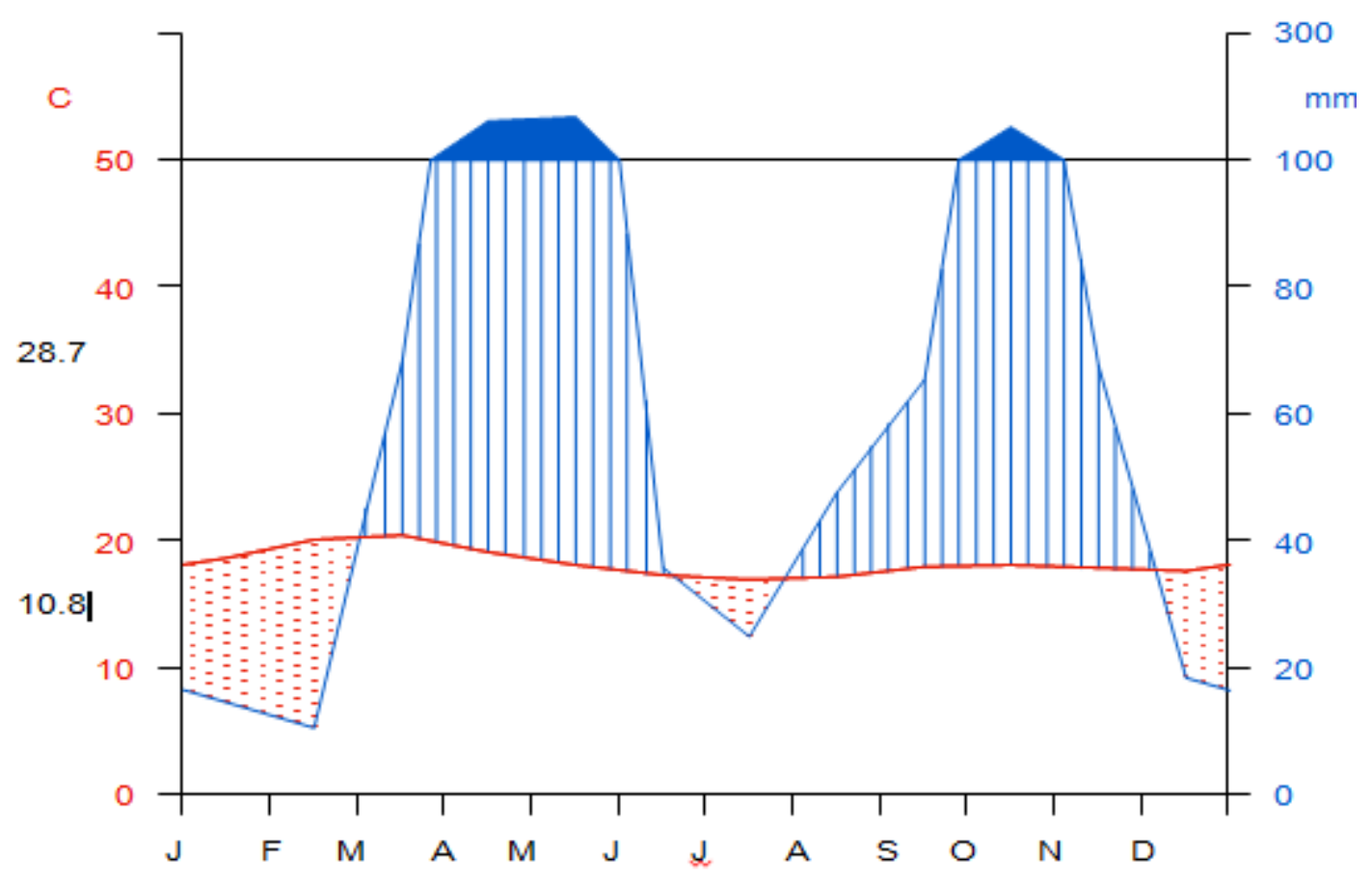

Figure 2

Climadiagram of Bule Hora Station (2004 - 2018). 


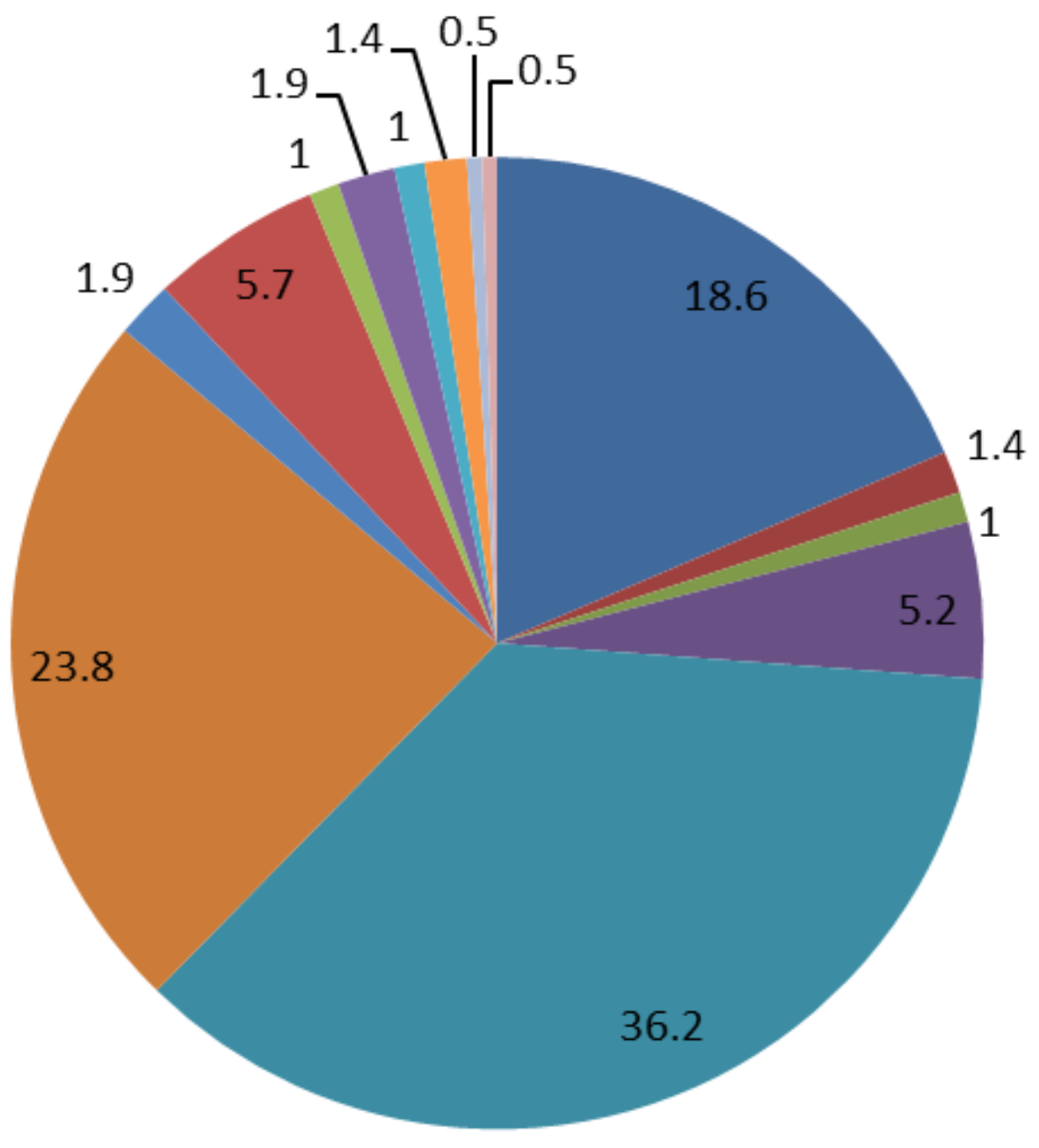

口 Bark

- Fruits

Gum

- Latex

Leaves

Root

Seeds

Stem

Leaves with barks

Leaves with leaves

Leaves with roots

Leaves with stems

Root with seeds

Seeds +bark + root

\section{Figure 3}

Parts of medicinal plants used for remedy preparation to treat human ailments in $\%$ 


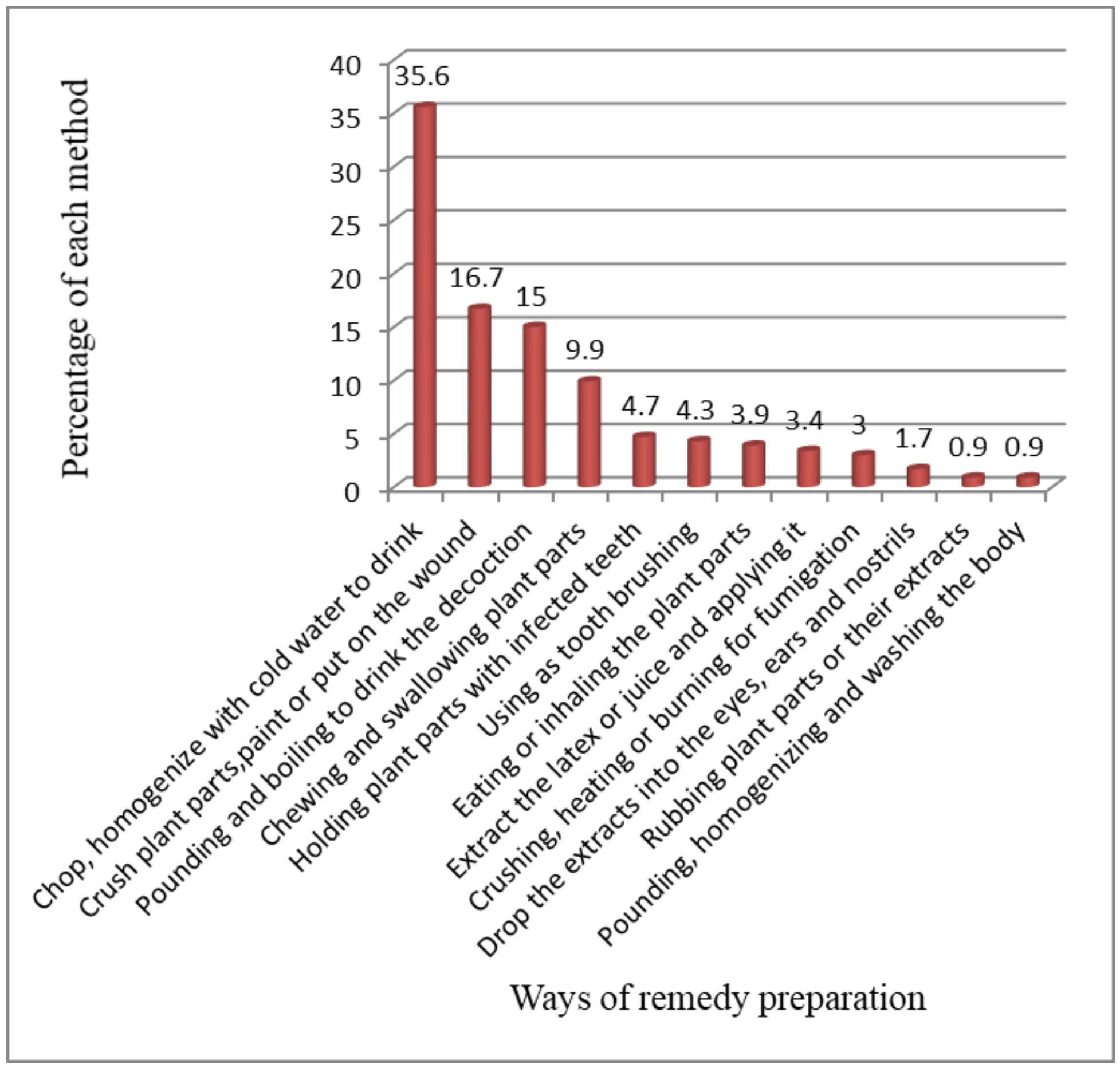

Figure 4

Ways of remedy preparation in treating human ailments in (\%) 


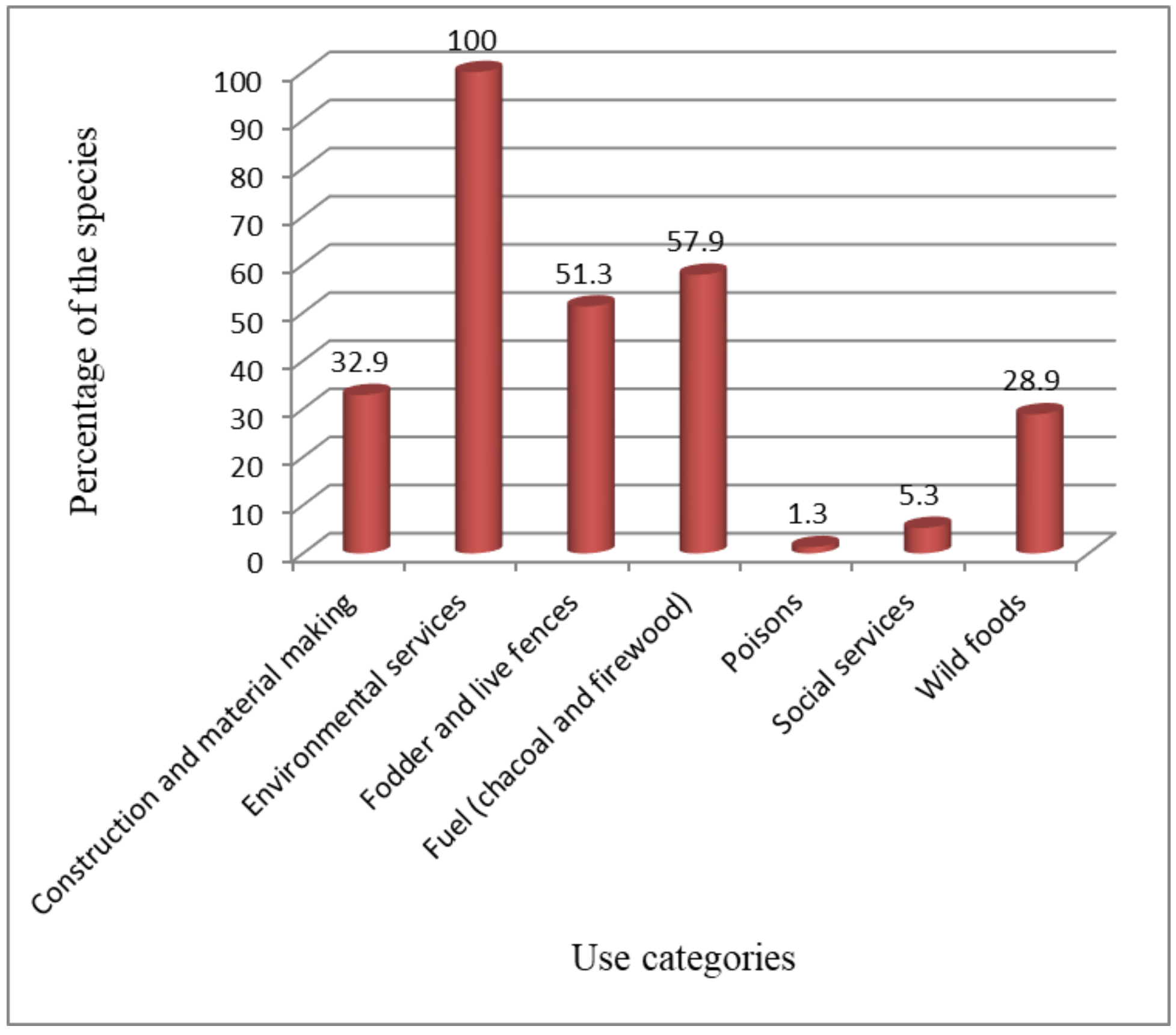

Figure 5

Proportion of human medicinal plants over different use categories 


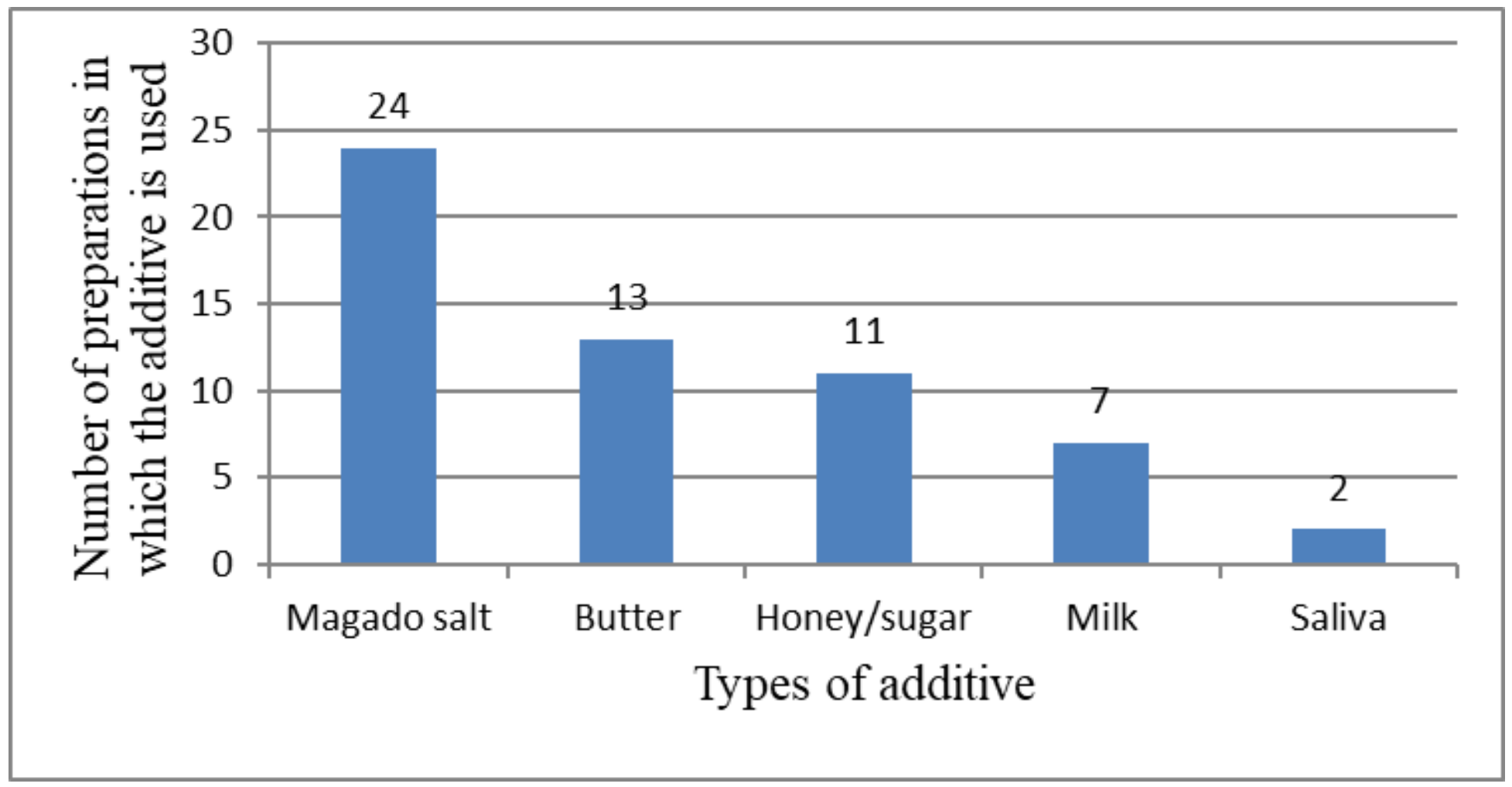

\section{Figure 6}

Additives used in the preparation of traditional remedies

\section{Supplementary Files}

This is a list of supplementary files associated with this preprint. Click to download.

- Table2.jpg

- Additionalfileofmedicinalplantsstudy.docx 